\title{
Impacts of Urban Land use changes on flood events in Warri, Delta State Nigeria
}

\author{
Aderoju Olaide $\mathrm{M}^{1}$, Okeke Onyedikachi. ${ }^{2}$, Nwadike Blessing $\mathrm{K}^{1}$, Eta Joseph ${ }^{1}$, \\ Onuoha Hilda $\mathrm{U}^{1}$, Ihenacho Nnaemeka $\mathrm{M}^{1}$, Eshiet Rejoice $\mathrm{I}^{1}$ \\ ${ }^{I}$ Department of Strategic Space Application, National Space Research and Development Agency (NASRDA), \\ Abuja, FCT, Nigeria. \\ ${ }^{2}$ Department of Mathematics, Osun State University, Osun State, Nigeria.
}

\begin{abstract}
Rapid industrial, commercial and economic growth in Warri as a result of oil exploration activities has led to a continual increasing urbanization. This promotes flooding with excess rainfall due to the total impervious cover of the area and the unsanitary habit of people dumping refuse into stream channels, drains and also building along the flood pathways. Land cover change for the period 1987, 2002 and 2007of Warri was investigated using satellite remote sensing data. The investigation was necessitated to determine the changes over time and how this changes influence urban flooding in Warri Metropolis Delta State, Nigeria. Landsat images of the study area for the years 1987, 2002, 2007 show that in 1987 total built-up area was $83.15 \mathrm{~km}^{2}$ (16.7\%) and by 2007 it was $236.76 \mathrm{~km}(43.7 \%)$ this reflect an annual frequency of change of $1.09 \%$. Marginal areas and vegetation were converted to residential areas which increased the total impervious cover of the study area and generally increased the peak runoff. The conversion of marginal areas also reduced the channel capacity thus leading to flooding. Questionnaires were also administered using the stratified and systematic sampling methods to get information on how the respondents perceive the cause of flood in the area, the data generated was subjected to ANOVA statistical tool using SPSS. The correlation matrix between Annual rainfall and frequency of flooding show that at $P<0.01, r=0.460$ indicating a very significant relationship. The single Factor ANOVA, $F>F$ crit at $P<0.05$ showed that an uncoordinated or unregulated urbanization activities is similar in all the flood zones (Warri 1- Warri 4).
\end{abstract}

Keywords: Urban flood, Urban centre, Urbanization, Land use change, Landsat.

\section{Introduction}

Urbanization is the process whereby large numbers of people congregate and settle in an area, eventually developing social institutions, such as businesses and government, to support themselves (Orum, 2004). It is usually the outcome of social, economic and political development that lead to urban concentration and growth of large cities, changes in land use and transformation from rural to metropolitan pattern of organization and governance (Angotti, 1993). Increased urbanization tends to have adverse effects on the environment.

Urbanization is accompanied by increasingly larger-scale urban spatial expansion as cities and towns swell and grow outwards in order to accommodate population increases. The 1950 estimated percentage of Nigeria's population living in the urban areas was $15 \%$, this rose to $19.2 \%$ in $1963,23.4 \%$ in 1975 and $35 \%$ in 1991 and presently estimated at 46\% (Onibokun and Kumuyi 1999; Oluwasola, 2007). By the 2005 National population Commission estimates, Nigeria has a population of 132 million, rate of urbanization $5.5 \%$ while the annual population growth is $3.0 \%$. By implication, approximately 60.7 million Nigerians are currently living in the urban areas.

The World Bank in 1993 estimated that the rural - urban migration is $84 \%$ this growth rate has vast implications on the urban land space. According to Adeleye and Oduwaye (2004) the morphology of Nigerian urban space has changed in a haphazard manner. The assertion of Adeleye and Oduwaye was echoed by UNDP (2006) that Nigerian cities are growing without adequate planning which has led to the decay in varying degree of the natural and human environment. The problems and challenges posed by this urban growth are immense which include the proliferation of slums and squatter settlements in the cities. The observable challenges are the human and environmental poverty, inadequate housing and associated facilities such that many now live in substandard environment plagued by slums, squalor and indiscriminate use of urban land space without due regard to existing land use policies (e.g. erection of mechanic workshops, waste dump sites, etc) which has contributed to urban flooding in many Nigerian cities (Onokerhoraye, 1980). Urban expansion alters the natural landscape; land uses and land cover as a result by changing water flows and increasing impermeable areas, thereby adding to the flood hazard problem (Satterthwaite 2011). Flooding are common features in Nigeria during Urban flooding which occurs in towns, on flat or low-lying terrain especially where little or no provision 
has been made for surface drainage, or where existing drainage has been blocked with municipal waste, refuses and eroded soil sediments (Folorunsho and Awosika 2001). Flooding cannot be completely avoided, but damages from severe flooding can be reduced if effective flood prevention scheme is implemented.

It is high time the Nigerian government decided on how to make the urban areas functionally efficient by the use of proper legislative act and policies. The knowledge of remote sensing and geographical information system (GIS) is a tool which can be used to investigate and map areas that are less or more vulnerable to flooding in conjunction with forecasting techniques to predict the precipitation intensity and duration in the nearest future (Aderoju et al, 2014). Geographic Information Systems (GIS) are widely used to analyze natural hazards such as landslides, flooding, among others (Aderoju et al, 2014). In this study, the use of remote sensing and GIS techniques with other ancillary data obtained from field survey will be combined to help in the understanding, monitoring, predicting and managing subsequent flood disasters occurrence in Warri. This study is aimed at investigating the land use change over time and how this changes influence urban flooding in Warri Metropolis.

\subsection{Objectives}

The objectives of this study is to;'

I. examine changes in urban growth in the Warri Metropolis using remotely sensed data and GIS techniques

II. identifying and mapping out the various land use change over time between 1987 and 2007,

III. Investigate the perception of the people on the cause(s) of flood in Warri and environs and how it has impacted their livelihood.

\section{The Study Area: Warri, Delta State}

In the Niger Delta Region of Nigeria, one city that has had its fair share of urban-rural pull is Warri in Delta State. Its history dates back to the 15th century, when it was visited by Portuguese missionaries (Ekeh, 2005). Warri is located on northern bank of Warri River about 30miles $(48 \mathrm{Km})$ upstream from the port of Forcados on the Bight of Benin. It is a conurbation of several communities including Warri, Effurun to the North, Ekpan to the West, Aladja to the East and the Bight of Benin to the Southwest. It has a coastline of approximately $160 \mathrm{~km}$ along the Bight of Benin. It occupies an area of about $499.81 \mathrm{~km}^{2}$. Located between Longitude $5^{0} 41^{\prime} 39.58^{\prime \prime} \mathrm{E}$ to Longitude $5^{0} 46^{\prime} 11.42^{\prime \prime} \mathrm{E}$ and Latitude $5^{0} 31^{\prime} 12.37^{\prime}{ }^{\prime} \mathrm{N}$ to Latitude $5^{0} 48^{\prime}$ $25.35^{\prime}$ 'N. Warri Metropolis is drained by an intricately woven network of rivers, creeks, river outlets and canals. It is a low-lying plain consisting mainly of recent unconsolidated sediments. There is marked absence of imposing hills that rise above the general land surface. The area experiences long raining season and short dry season. Mean annual rainfall is about 2,716.89mm (Table 6). Relative humidity oscillates between 80 and 90\%. There is dense cloud cover for most of the year with an average annual temperature is about $27^{\circ} \mathrm{C}$.

\subsection{Population Size and Growth of Warri}

According to Onokerhoraye (1980), there was a considerable movement of population within the State between 1952 and 1963 as a result, the growth rate of Warri rose to $6.71 \%$ and by 1991 National population census, when Delta State rose in population figure to 2,570,181; the population of Warri Metropolis rose to 363,382 (i.e. Warri town $(217,584)$, Effurun $(123,610)$ Ovwian $(22,188)$. The 2006 population of Warri town (excluding the towns of Ekpan, Aladja and Ovwian) was 303,417. The rapid urban growth which Warri has experienced stemmed from its position as the headquarters of Warri South LGA and the zonal headquarters of federal parastatals as well as the oil and gas industry such as Nigeria National Petroleum Company (NNPC), Shell Petroleum Development Company (SPDC), many shipping and allied companies which have provided employment opportunities. The establishment of Warri Refinery and Petrochemical Company as well as the Aladja Steel Complex and its associated companies has in no doubts contributed to the rapid population growth as well as the urbanization process. 


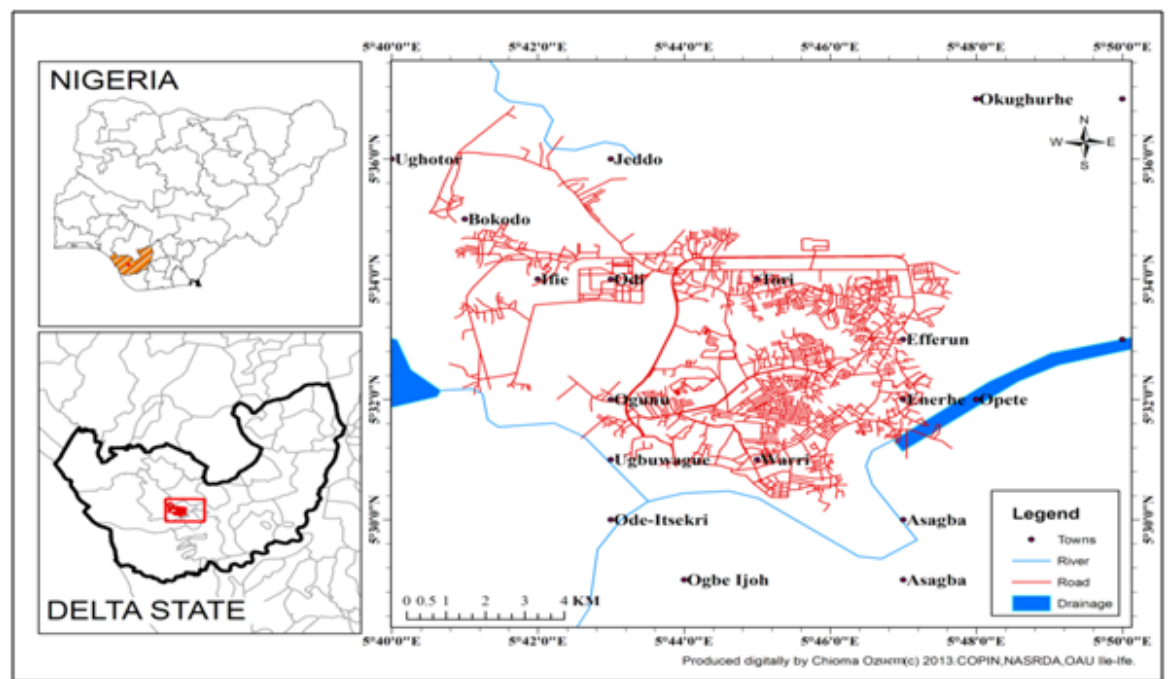

Figure 1: Map of Nigeria showing the Study Area

\subsection{Urban land use changes on flood events in Warri}

Growing urban population results in large areas of land surface covered with roofing materials, concrete and bitumen pavement which reduce infiltration of rainwater and increase surface runoffs leading to flood in the cities with adverse economic effect and health impact Ogbonna et al., (2008). Unplanned urbanization also results in property development in marginal areas and the unhealthy practice of dumping refuse into drains etc, (Agobie, 2013; Gobo, 2007). Odemerho (2004) and Nwafor (2006) identified 12 causes of urban flooding. These includes the surcharges in water level due to natural or man-made construction on flood path, sudden dam failure, inappropriate land use, mudflow, inadequate drainage capacity to cope with urbanization, excess encroachment in flood ways, ice jam, rapid snow fall, deforestation of catchment basins, reclamation, construction sites and solid waste.

According to Njoku et al (2013) this practice has led to urban flooding in some Nigerian cities like Port Harcourt, Aba, Lagos and Ibadan. Basically cities in coastal areas experiencing unplanned and unregulated urban expansion and population growth experience two types of flood regimes: Urban or flash flood and tidal flood or coastal inundation. A third type, channel floods can occur in urban towns that are traversed by major river systems. All of these floods can occur at the same time or independently depending on the weather and astronomic spring conditions.

Urban flood refers to the inundation of sections of urban areas which can be caused by a combination of high intensity rainfall and prolong rainfall leading to the development of flash floods (Gobo and Abam 1991). Warri being a coastal community experiences an average of 2,716.89mm of rainfall annually between 1977 and 2007 (Table 6). Flood events are recent to Warri compared to other coastal cities like Port Harcourt, Lagos and Bonny. Flooding generally was not a common occurrence in Warri but however, it has become a common feature in the Warri Urban space in recent years with several houses and streets remaining under water for several days (Fig 2.0). This large and evolving challenge needs investigation to avert associated risks and hazards of flooding. Understanding flood hazards requires a better comprehension of the types and causes of flooding, their probabilities of occurrence, and their expression in terms of extent, duration, depth and velocity (Nwoke and Okoro, 2012). This understanding is essential in designing measures and solutions which can prevent, or limit damage from specific types of flood. Equally important is to know where and how often flood events are likely to occur, what population and assets are at risk, how vulnerable the people who resides in the potentially flooded areas are.

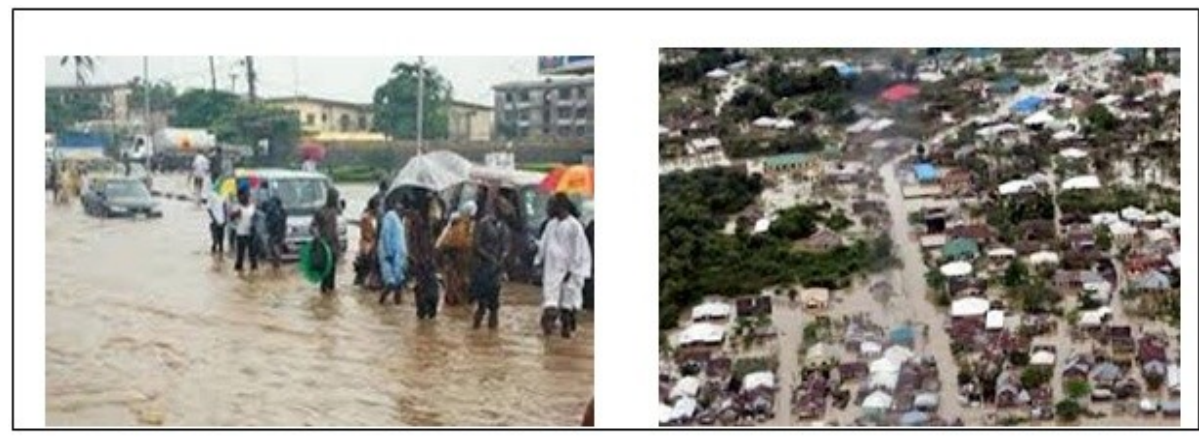

Figure2.0 Various Flood Scenarios in Warri and Environs between 1987 and 2007 


\section{Materials and Method}

i. Landsat images of 1987, 2002 and 2007 as well as Administrative map of Delta State were sourced from SPDC and Ministry of Land and Survey. ArcGIS 9.3 and ILWIS 3.3 software were employed to analyze the images. A supervised classification (Maximum likelihood algorithm) was performed on false colour composite (bands 4, 3 and 2) into the following land use and land cover classes; Built-up area, Forest, Mangrove Forest, and water bodies. The results are presented in form of maps. Change Detection method was used to compare the various Landsat imageries collected over the same area at different times and to highlight features that have changed, area calculation in $\mathrm{km}^{2}$ for each classes was done and the results are presented in form of tables, charts and graphs.

\begin{tabular}{|l|l|l|l|l|l|l|}
\hline S/N & Name & $\begin{array}{l}\text { Path \& } \\
\text { Row/sheet no }\end{array}$ & Date & Format & Source & Scale/Resolution \\
\hline 1 & Landsat TM & $\mathrm{p} 189, \mathrm{r} 56$ & 1987 & Digital & RECTAS & $30 \mathrm{~m}$ \\
\hline 2 & Landsat ETM+ & $\mathrm{p} 189, \mathrm{r} 56$ & 2002 & Digital & RECTAS & $30 \mathrm{~m}$ \\
\hline 3 & Landsat ETM+ & $\mathrm{p} 189, \mathrm{r} 56$ & 2007 & Digital & SPDC & $30 \mathrm{~m}$ \\
\hline 4 & $\begin{array}{l}\text { Administrative map } \\
\text { of Delta state }\end{array}$ & First Edition & 2000 & Digital & $\begin{array}{l}\text { Directorate of } \\
\text { lands and } \\
\text { survey, } \\
\text { Asaba. }\end{array}$ & $1: 300,000$ \\
\hline
\end{tabular}

Table 1.0: Satellite Remote Sensing Data format \& Sources

ii. Based on a field reconnaissance survey of flooded portions of the city, communities were clustered to form flood zone communities using the principle of nearest neighbor. Questionnaires were then administered to the residents (from Age 18years and above per house hold) using the stratified and the systematic sampling methods in other to elicit their perception of the causes of flood in the area, the degree of damage done by flood, flood frequency and impact etc. The flood communities were classified into 4 groups which include Warri 1 , Warri 2, Warri 3 and Warri 4 respectively.

a) Warri 1 comprises of Warri main, Ekurede Itsekire, Ajamogha, NPA, GRA, Okere, Eboh, Igbudu, Essi layout.

b) Warri 2 comprises of Okumagba layout, Ugborikoko, Enerhen.

c) Warri 3 comprises of Ogunu, Ekurede Urhobo, Edegba, NNPC, Ekpan, and Military Barracks.

d) Warri 4 comprises of Effurun, Ugboroke, Bendel Estate, and Isokoh Estate.

Information obtained from the respondent of the questionnaires during the survey was further subjected to statistical analysis using the Statistical Package for Social Scientist (SPSS) version 17.

iii. Daily rainfall data for the period $1977-2007$ was sourced from the Nigeria Meteorological Services (NIMET) synoptic Station archives in Warri.

\section{Results}

\subsection{Land Use/Urban Growth of Warri}

The land use and urban growth of Warri Metropolis for 1987, 2002 and 2007 is presented below as figures 3.0, 4.0 and 5.0. This simply shows different type of land cover present in Warri and also the corresponding land use. The interpretation of this classified mages has display the rapid land use change in Warri from the year 1987 to 2007.

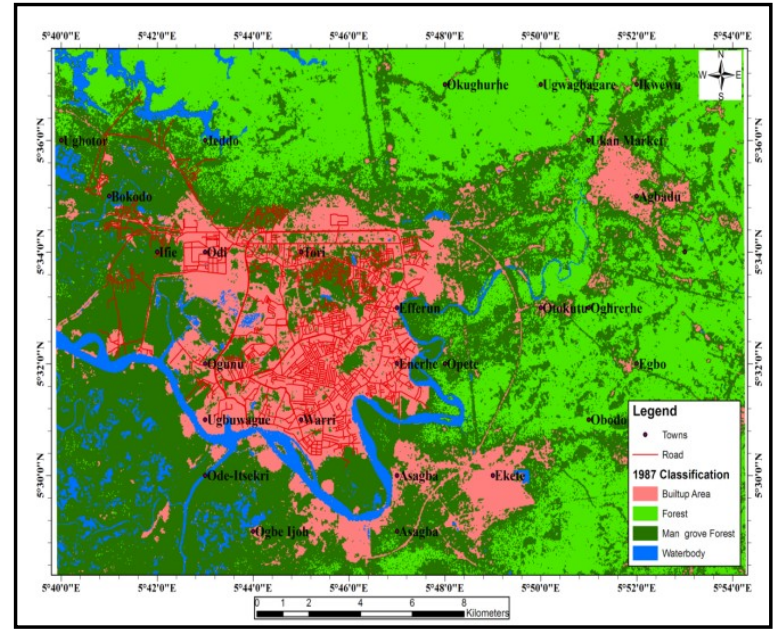

Figure 3.0: 1987 Classified Image of Warri. 


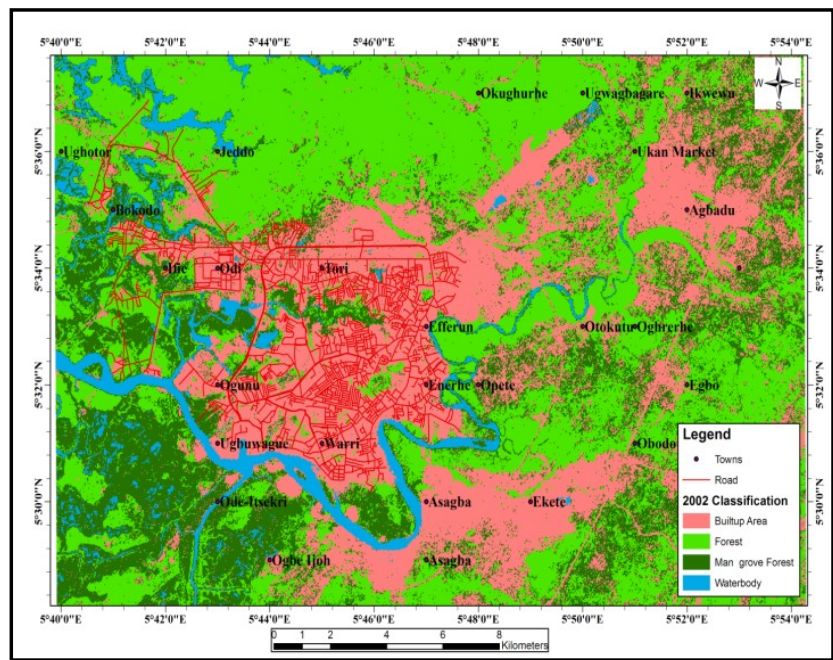

Figure 4.0: 2002 Classified Image of Warri.

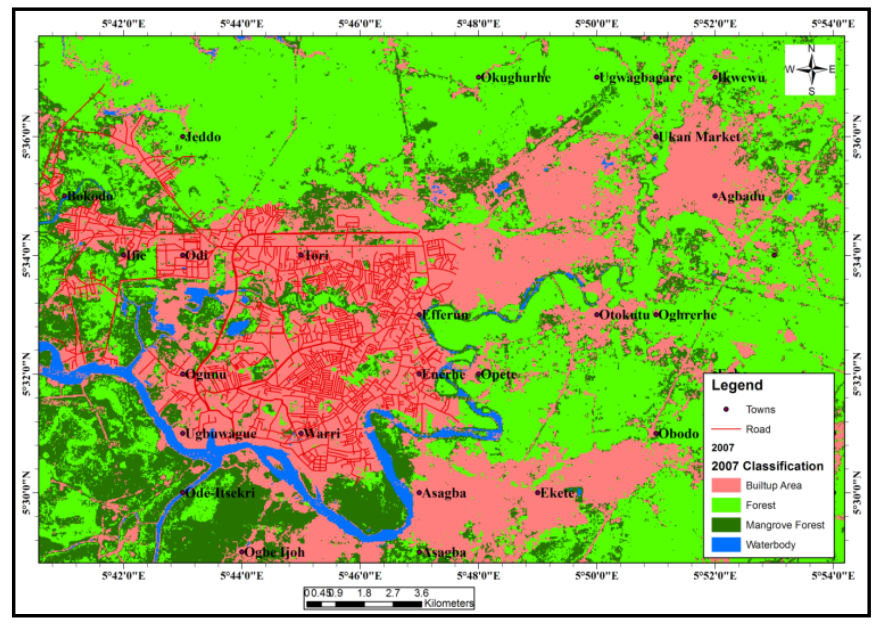

Figure 5.0: 2007 Classified Image of Warri.

\subsection{Statistics of the classified images}

The figure 6.0 below shows both the statistics of the classified images (1987, 2002 and 2007) and also the table displaying the total area occupied by each Land use type in Warri. The histogram shows ranges of the Land use and its changes over the years while the table shows the area in $\mathrm{Km}^{2}$ occupied by each Land use over the years 1987 to 2007. The table 2.0 shows the percentage change of the Landuse type between 1987 to 2007.

\begin{tabular}{|c|c|c|c|c|}
\hline \multirow{6}{*}{ 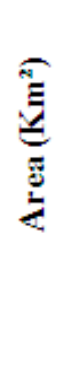 } & \multirow{4}{*}{$\begin{array}{r}250 \\
200 \\
150 \\
100 \\
50\end{array}$} & & & \\
\hline & & & & \\
\hline & & & & \\
\hline & & & & \\
\hline & \multirow{2}{*}{0} & Area $\left(\mathrm{Km}^{2}\right)$ & Area $\left(\mathrm{Km}^{2}\right)$ & \multirow{2}{*}{$\begin{array}{c}\text { Area }\left(\mathrm{Km}^{2}\right) \\
2007\end{array}$} \\
\hline & & 1987 & 2002 & \\
\hline \multicolumn{2}{|c|}{ - Builtup Area } & 83.15 & 155.56 & 236.76 \\
\hline \multicolumn{2}{|c|}{ Mangrove Forest } & 214.59 & 114.56 & 157.3 \\
\hline \multicolumn{2}{|c|}{ Forest } & 173.55 & 203.85 & 92.73 \\
\hline \multicolumn{2}{|c|}{ - Water Body } & 28.1 & 25.34 & 12.6 \\
\hline
\end{tabular}

Figure. 6.0 Total Area occupied by Land use types for 1987, $2002 \& 2007$ classified images of Warri 
Impacts of Urban Land use changes on flood events in Warri, Delta State Nigeria

\begin{tabular}{|l|l|l|l|l|l|}
\hline & $\mathbf{1 9 8 7}$ & $\mathbf{2 0 0 7}$ & Magnitude of change & $\begin{array}{c}\text { Annual Change } \\
\text { Frequency }\end{array}$ & $\begin{array}{l}\text { Percentage of change } \\
(\mathbf{\%})\end{array}$ \\
\hline Built-up Area & 83.15 & 236.76 & 153.61 & 1.09 & 184.7 \\
\hline Mangrove Forest & 214.59 & 157.3 & -57.29 & -0.31 & -0.26 \\
\hline Forest & 173.55 & 92.73 & -80.82 & -0.35 & -0.46 \\
\hline Water Body & 28.1 & 12.6 & -15.5 & -0.26 & -0.55 \\
\hline Sum & 499.39 & 499.39 & & & \\
\hline
\end{tabular}

Table 2.0: Annual Change Frequency and Percentage Change

\begin{tabular}{|c|c|c|c|}
\hline \multirow{3}{*}{$\begin{array}{r}500 \\
0\end{array}$} & 83.15 & 155.56 & 236.76 \\
\hline & 1987 & 2002 & 2007 \\
\hline & & an $\mathrm{Ar}$ & \\
\hline
\end{tabular}

Figure 7.0 Variations in the Urban Area in Warri.

\subsection{Perception of the People to the Flood events}

The tables below show how the residents of the flooded areas in Warri perceive the problems of flood (the causes of flood, magnitude of flood and the financial implications of those impacted).

\begin{tabular}{|l|l|l|l|l|}
\hline Causes of Flood & Warri 1 & Warri 2 & Warri 3 & Warri 4 \\
\hline Heavy Rainfall & 80 & 79 & 82 & 80 \\
\hline Lack of Drains & 24 & 27 & 25 & 28 \\
\hline Blocked Drains & 30 & 19 & 28 & 25 \\
\hline Defective Drains water & 16 & 20 & 18 & 19 \\
\hline $\begin{array}{l}\text { Building along } \\
\text { ways }\end{array}$ & 52 & 40 & 42 \\
\hline $\begin{array}{l}\text { Uncontrolled property } \\
\text { Dev. }\end{array}$ & 20 & 22 & 27 & 26 \\
\hline Total Respondents & 220 & 220 & 220 & 220 \\
\hline
\end{tabular}

Table 3.0 Causes of Flood

\begin{tabular}{|ll|r|r|}
\hline & & Annual Rainfall & \multicolumn{2}{|c|}{ Frequency Flooding } \\
\hline Annual Rainfall & Pearson Correlation & 1 & $.460^{* *}$ \\
& Sig. (2 tailed) & 31 & .009 \\
& $\mathrm{~N}$ & $.460^{* *}$ & 31 \\
\hline Freq_Flooding & Pearson Correlation & .009 & 1 \\
& Sig. (2 tailed) & 31 & 56 \\
\hline & $\mathrm{N}$ & & \\
\hline
\end{tabular}

** Correlation is significant at the 0.01 level ( 2 tailed).

Result: $\mathrm{r}=0.460$ at $\mathrm{P}<0.01$.

Table 3.1 SPSS output of Correlations Analyses

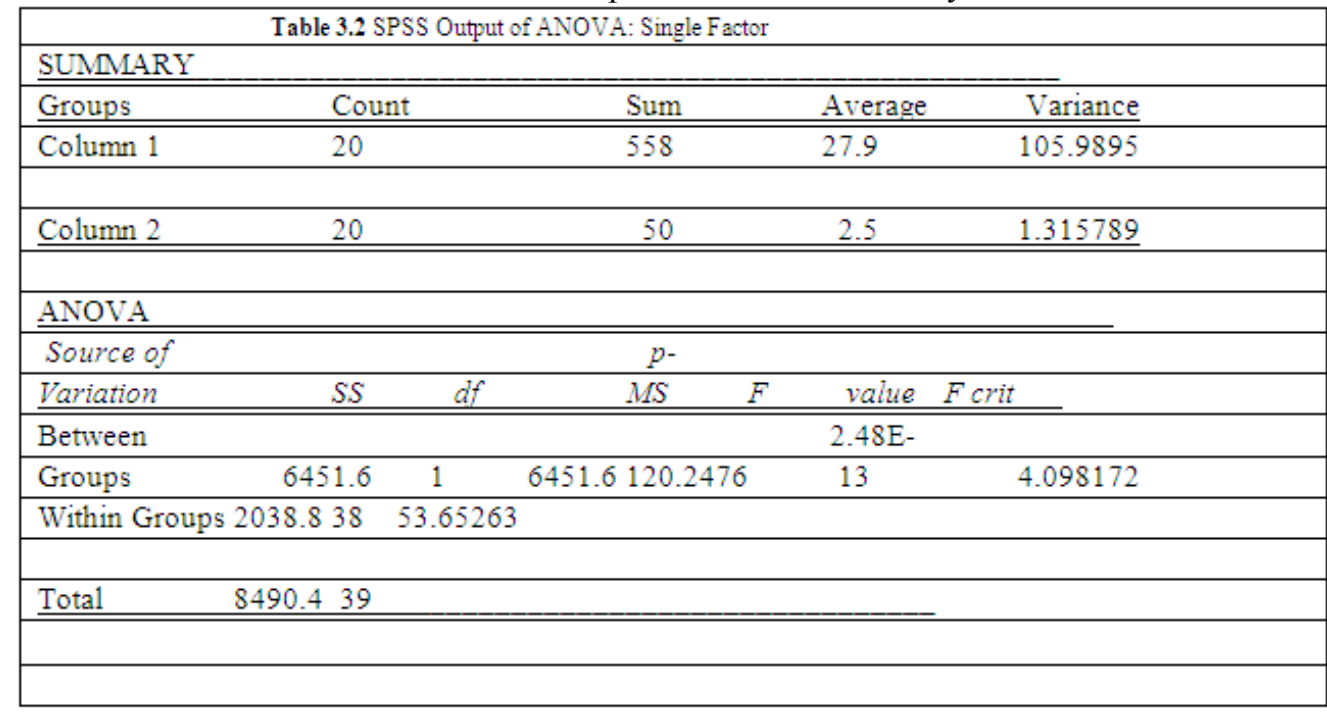


Impacts of Urban Land use changes on flood events in Warri, Delta State Nigeria

\begin{tabular}{|l|l|l|l|l|}
\hline & Warri 1 & Warri 2 & Warri 3 & Warri 4 \\
\hline $\begin{array}{l}\text { Most part of the } \\
\text { community are flooded }\end{array}$ & 38 & 35 & 32 & 30 \\
\hline $\begin{array}{l}\text { The whole street is } \\
\text { flooded }\end{array}$ & 56 & 58 & 54 & 57 \\
\hline $\begin{array}{l}\text { Whole household is } \\
\text { flooded }\end{array}$ & 30 & 43 & 36 & 38 \\
\hline $\begin{array}{l}\text { Most streets in the area } \\
\text { are flooded \& }\end{array}$ & 28 & 42 & 34 & 31 \\
\hline $\begin{array}{l}\text { Movement activities } \\
\text { Commercial } \\
\text { hindered }\end{array}$ & 20 & 21 & 22 \\
\hline $\begin{array}{l}\text { Roads are blocked for } \\
\text { upward of 3hrs }\end{array}$ & 24 & 11 & 25 & 23 \\
\hline Total Respondents & 220 & 220 & 220 & 220 \\
\hline
\end{tabular}

Table 3.3 Respondents on flood impact in Warri.

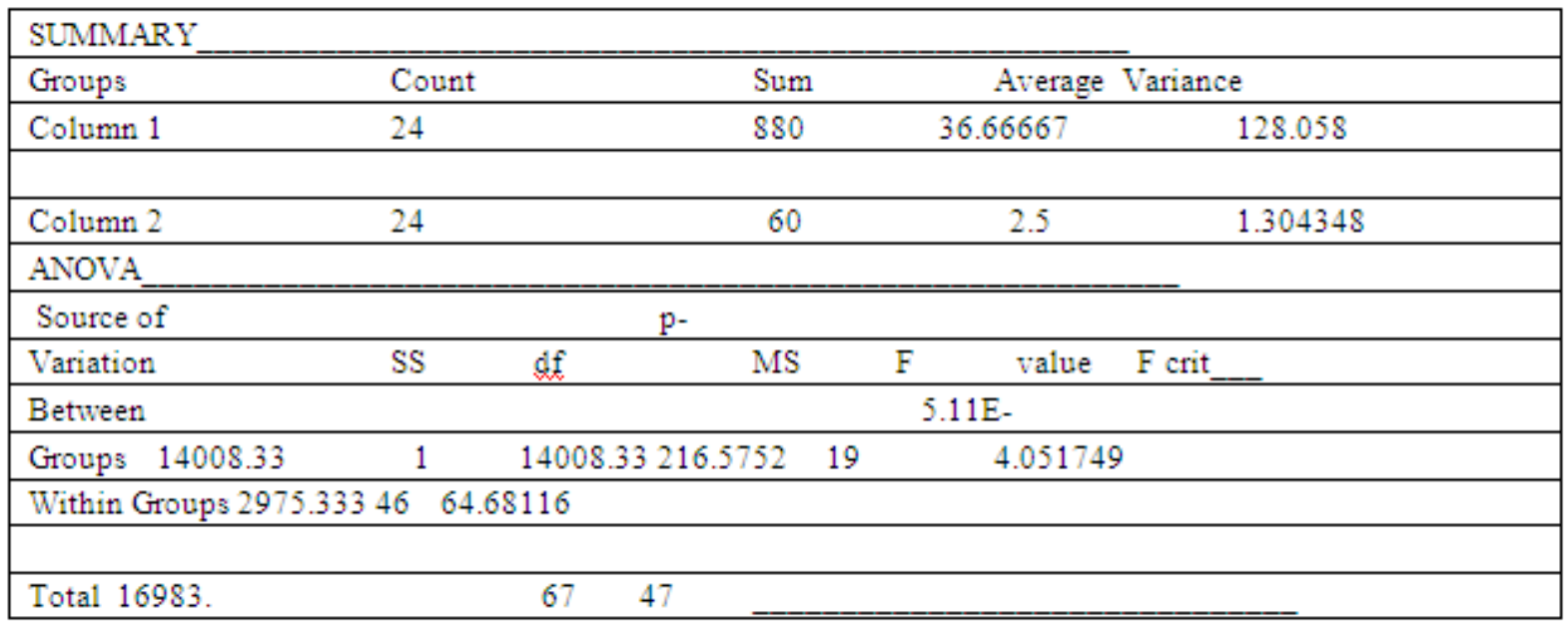

Table 3.4 SPSS out for ANOVA: Single Factor

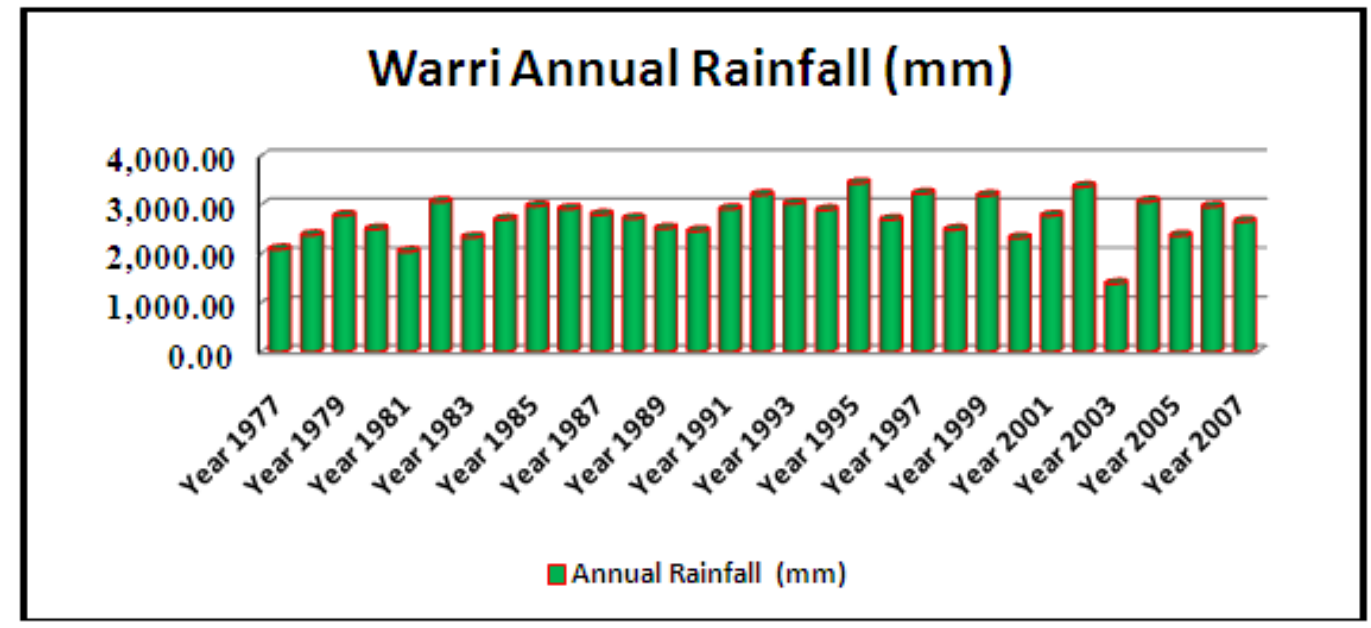

Figure 8.0 Warri Annual for 30 years

\section{Discussion}

The Classified Landsat images of Warri for the years 1987, 2002 and 2007 showed that the urban growth of Warri city experienced an overall increase in the built-up area by $184.7 \%$ from about $83.15 \mathrm{~km}^{2}$ $(16.7 \%)$ in $1987,155.56 \mathrm{~km}^{2}(32.1 \%)$ in 2002 and finally $236.76 \mathrm{~km}^{2}(47.3 \%)$ in 2007 . All other land use or land cover classes such as mangrove forest, forest, and water bodies experience reduction as man convert these covers into residential and commercial uses. In terms of magnitude of change, Built-up area has 153.61 with an annual Frequency of change of $1.09 \%$ and percentage change of $184.7 \%$. No other land uses experience this magnitude of change. This extensive growth creates difficulties in the lack of adequate infrastructure and creates various negative environmental impacts. Several of the most obvious changes are the loss of valuable vegetation 
including agricultural lands. For instance, the conversion of forest areas into urban use increased the total impervious cover of the City while the conversion of marginal areas like floodplains and river corridors contributes to the reduction in channel carrying capacity of the streams; this is reflected in the channel in-ability to accommodate peak surface runoff which leads to the catastrophic floods experienced in the area, flooding occurs very quickly due to faster flow times, sometimes in a matter of minutes.

These suburb are not planned into conventional design layouts and are not well linked to others for accessibility purposes., beyond the immediate social ills such as unemployment, poor quality of housing, traffic congestion, poverty, poor quality of standard of living, overcrowding (which put pressures on the State and local governments to provide basic social amenities and infrastructures for the growing population), they contribute to the overall total impervious layer of Warri which translates into surface runoffs whenever there is precipitation. The discovery \& exploration of crude oil couple with rapid industrial, commercial and economic growth of Warri city influenced the Immigrants from the rural hinterland leading to population pressure on the existing housing facility, this has led to the uncoordinated development of the marginal lands and suburbs of the city thereby leading to the development of squatter's settlement at the pre-urban zones (Warri 3 and Warri 4).

The rainfall pattern of the area is typical of a coastal settlement couple with global climate change. Table 5; indicate that rainfall of $2,600 \mathrm{~mm}$ can fall $50 \%$ of the time within a given raining season, coupled with increasing impervious cover, reduction of the channel carrying capacity as a result of encroachment as well siltation/blockages resulting from dumping of refuse into flooding can be expected in the areas highlighted in this study. This observation is in alignment with the perception of the residents in Warri (Tables 3.1 and 4.1) the correlation matrix between Annual rainfall and frequency of flooding show that at $\mathrm{P}<0.01$, the $\mathrm{r}=0.460$ indicating a very significant relationship (table 3.2). Furthermore, the single Factor ANOVA, F $>\mathrm{F}$ crit at $\mathrm{P}<$ 0.05 (table3.3) shows that uncoordinated or unregulated urbanization activities is similar in all the flood zones (Warri 1- Warr4). Unregulated urban land use translate into building on flood pathways, dumping of refuse into water ways etc and may in addition to other factors contribute to the recent flood events experienced in the city. The perception of the respondents on the spread and impacts of flood across the four flood zones show that there is no significant difference on the spread or impact.

\section{Conclusion}

Vital infrastructure has been the attraction for rural-urban migration in Nigeria. Rapid urbanization, particularly the growth of large cities, and the associated problems of unemployment, poor sanitation, urban slums and environmental degradation pose a formidable challenge in many developing countries. Warri Metropolis has experienced accelerated growth in its urban space from about $83.15 \mathrm{~km}^{2}$ in 1987 to $236.76 \mathrm{~km}^{2}$ in 2007. The city grew by $184.7 \%$ in twenty years with an annual frequency of change into urban space at 1.09 . This urban growth has led to the unregulated development of marginal areas which has affected both the land cover/ land use and by extension increased the total impervious cover of the area on the one hand and the unsanitary habit of people dumping refuse into stream channels, drains and also building along the flood pathways. It is evident that increasing impervious cover due to an abrupt increase in urbanization in Warri as a result of discovery and exploration of crude oil couple with rapid industrial, commercial and economic growth promotes runoff, some other likely factors that can bring about flooding with excess rainfall. It was also deduced from statistics that unregulated urbanization activities is similar in all the flood zones (Warri 1- Warr4). The perception of the respondents on the urban spread and impacts of flood across the four flood zones is similar.

\section{Recommendation}

The area expansion of Warri metropolis is now over $100 \mathrm{~km}^{2}$ with a bourgeoning population there is needed to control urban sprawl and land use change. New city concepts in planning should be adopted in developing small towns around Warri city. This will absorb the excess population of the city, and reducing spatial expansion of this city to adjoining marginal lands. Development and legislative measures should be adopted as to regulate growth in the study area by urban planners, town administrators, ministries etc. A proper waste management program should be properly operated and managed. In all arms of the government (federal, state and local), ideal governance should be promoted and practiced so that the right people with related professional experience are appointed into the political positions that have to do with environment, physical planning and urban development, and other departments in government in order to ensure and increase productivity and sustainable development.

\section{References}

[1]. Adeleye O.A and Oduwaye, L (2004) Correlates of Land Value Determinants in Lagos Metropolis, Nigeria, Journal of Human Ecology, (3) 183-189

[2]. Aderoju O.M, Jantiku J, Fagbemiro O.A, Aliyu I, Nwadike B.K, Ajonye S.E, Salman K.S (2014). Geospatial Assessment of 2012 Flood Disaster in Kogi State, Nigeria. IOSR. Journal of Environmental Science, Toxicology and Food Technology (IOSRJESTFT) e-ISSN: 2319-2402, P-ISSN: 2319-2399. Volume 8; issue 2 Ver IV (March- April. 2014) Pp 74-84. 
[3]. Angotti, T (1993) Metropolis 2000: Planning, Poverty and Politics. London, Routledge

[4]. Agobie, O.I ( 2013). Implementation of Physical Planning Laws and Its Implication on flood control in Warri Niger Delta. Unpublished M.Phil Thesis, Institute of Geosciences and Space technology, Rivers State University of Science and Technology. Port Harcourt Nigeria.

[5]. Ekeh, P. P. (2005). Warri City and British Colonial Rule in Western Niger Delta. Urhobo Historical Society. p. 31. ISBN $\underline{978-064-}$ 924-7.

[6]. Folorunsho, R. and L. Awosika, (2001). Flood Mitigation in Lagos, Nigeria Through Wise

[7]. Management of Solid Waste: a case of Ikoyi and Victoria Islands; Nigerian, Paper

[8]. presented at the UNESCO-CSI workshop, Maputo 19-23 November 2001.

[9]. Gobo, A.E., and Abam, T.K.S (1991). The 1988 Floods in the Niger Delta: The Case of Ndoni. The Journal of Meteorology. Vol.16. No.163

[10]. Njoku, J.D; A. G.T and Duru, P.N (2013) Spatial Assessment of Urban flood risks in Aba Metropolis, using geographical Information Systems techniques. Global Advance Research Journal of Environmental Science and Technology. Vol.2(3) pp 86-92 online version http/garj.org/garjest/index.htm

[11]. Nwafor, J.C., 2006. Environmental Impact Assessment for Sustainable Development: The

[12]. Nigerian perspective. Enugu: EL 'DEMAK pubs, pp. 359-394.

[13]. Nwoke, H.U and Okoro B.C (2012). Rainfall Intensity-Frequency Regime for Warri, South-South Nigeria. New Clues in Sciences 2. p 42-49. www.waoj.org/NCS

[14]. Odemerho F.O., 2004. Benin City: A Case Study of Urban Flood Problems" In Sada P.O and Odemerho F. O (eds) Environmental Issues and Management in Nigeria development. Evans Brothers Nig. Publishers Ltd.

[15]. Ogbonna, D.N.; Chilaka S. N and A G.T. (2008) Health Implications of poor waste Disposal Practices and Perennial Flooding in Port Harcourt Metropolis, Nigeria. Journal of Research in Bioscience vol. 4 issue 3 p.103 -110 www.irdionline.com

[16]. Ogbonna, D.N.; A G.T. and Itulua, P.A (2011) Study of the nature of urban flood in Benin City, Edo State; Nigeria. Global Journal of Pure and Applied Sciences. Vol. 17 No.1 p 7 -21

[17]. Oluwasola,o (2007) Social Systems, Institutions and Structures: Urbanization, Poverty and Changing Quality of Life, Proc. of the training session of the foundation for environmental development and education in Nigeria, Port Harcourt.

[18]. Onokerhoraye, A. G. and Omuta, G.E.D (1994) Urban Systems and Planning for Africa. The Benin Social Science Series for Africa.

[19]. Onokerhoraye, A.G (1980) Perspectives on public policy and social research in rural development in Nigeria. Quarterly Journal of Administration, Vol,15 (3) p $183-192$

[20]. Onibokun, A.G. \& Kumuyi A. J. (1999). Waste management in Ibadan, Nigeria. In Onibokun, A. G. (Ed). (2004). Managing the monster: Urban waste and governance in Africa. Canada, International Development Research Centre (IDRC). www.idrc.ca/publication/online books on 20/11/06)

[21]. Orum, A (2004). "Urbanization." Encyclopedia of Social Theory. 2004. SAGE Publications. 19 Mar. 2011 Satterthwaite W.H and Carlson S.M 2011. Weakened portfolio effect in a collapsed salmon population Complex. NRC Research Press 2011. 